\title{
Correction to: Behavioral Artistry: Examining the Relationship Between the Interpersonal Skills and Effective Practice Repertoires of Applied Behavior Analysis Practitioners
}

\author{
Kevin Callahan ${ }^{1} \cdot$ Richard M. Foxx $^{2} \cdot$ Adam Swierczynski $^{1} \cdot$ Xing Aerts $^{1} \cdot$ Smita Mehta $^{3} \cdot$ Mary-Ellen McComb $^{1}$. \\ Susan M. Nichols ${ }^{1} \cdot$ Gabrielle Segal $^{1} \cdot$ Andrew Donald $^{1} \cdot$ Rachita Sharma $^{4}$
}

Published online: 28 August 2019

(c) The Author(s) 2019

\section{Correction to: Journal of Autism and Developmental Disorders (2019) 49:3557-3570 https://doi.org/10.1007/s10803-019-04082-1}

The article Behavioral Artistry: Examining the Relationship Between the Interpersonal Skills and Effective Practice Repertoires of Applied Behavior Analysis Practitioners, written by Kevin Callahan, was originally published electronically on the publisher's internet portal (currently SpringerLink) on August 29, 2019 without open access.

With the author(s)' decision to opt for Open Choice the copyright of the article changed on August 2019 to $($ ) The Author(s) 2019 and the article is forthwith distributed under the terms of the Creative Commons Attribution 4.0 International License (http://creativecommons.org/licen ses/by/4.0/), which permits use, duplication, adaptation, distribution and reproduction in any medium or format, as long as you give appropriate credit to the original author(s) and the source, provide a link to the Creative Commons license and indicate if changes were made.

The Original article has been corrected.

Open Access This article is distributed under the terms of the Creative Commons Attribution 4.0 International License (http://creativeco mmons.org/licenses/by/4.0/), which permits unrestricted use, distribution, and reproduction in any medium, provided you give appropriate credit to the original author(s) and the source, provide a link to the Creative Commons license, and indicate if changes were made.

Publisher's Note Springer Nature remains neutral with regard to jurisdictional claims in published maps and institutional affiliations.

The original article can be found online at https://doi.org/10.1007/ s10803-019-04082-1.

Kevin Callahan

callahan@unt.edu

1 Kristin Farmer Autism Center (KFAC), University of North Texas (UNT), 490 S. Interstate 35 East, Denton, TX 76205 , USA

2 Pennsylvania State University College of Medicine, Hershey, USA

3 Department of Educational Psychology, UNT, Denton, USA

4 Department of Rehabilitation and Health Services, UNT, Denton, USA 